\title{
Determination of Heavy Metals and Organochlorine Pesticides in the Leaves and Flowers from Linden Trees in Kırklareli Province
}

\author{
Osman Üner*, Cihan Torlak, Cemile Özcan
}

Department of Chemistry, Kırklareli University, 39020 Kırklareli, Turkey, osmanuner@klu.edu.tr

\begin{abstract}
For five different regions in Kirklareli province, heavy metals; such as $\mathrm{Pb}, \mathrm{Ni}, \mathrm{Cu}, \mathrm{Mn}, \mathrm{Cd}, \mathrm{Cr}, \mathrm{Co}, \mathrm{Zn}, \mathrm{Mo}$, and Fe in the mixture of leaves and flowers from linden trees (Tilia tomentosa L.) were analyzed by using flame atomic absorption spectroscopy after the samples were dissolved with microwave method. Also, organochloride pesticides; such as $\sum$ BHC: [ $\alpha$-BHC, $\beta$-BHC, $\gamma$-BHC, and $\delta$-BHC], $\sum$ DDT: [4,4'-DDD, 4,4'-DDE, and 4,4'-DDT], $\alpha$-Endosulfan, $\beta$-Endosulfan, Endosulfan sulfate, Heptachlor, Heptachlor-endo-epoxide, Aldrin, Dieldrin, Endrin aldehyde, Endrin ketone, Endrin and Methoxychlor in these samples were determined by utilizing gas chromatography mass spectroscopy after the samples were prepared for analyses by using QuEChERS method. The metal concentrations in the samples were in the range of 45.3 to $268 \mathrm{mg} / \mathrm{kg}$ for $\mathrm{Mn}, 0.25$ to $18.8 \mathrm{mg} / \mathrm{kg}$ for $\mathrm{Cu}, 11.5$ to $46.1 \mathrm{mg} / \mathrm{kg}$ for $\mathrm{Zn}, 128$ to 1310 $\mathrm{mg} / \mathrm{kg}$ for Fe, 10.4 to $38.6 \mathrm{mg} / \mathrm{kg}$ for Mo, 0.82 to $1.34 \mathrm{mg} / \mathrm{kg}$ for Cd, 0 to $6.45 \mathrm{mg} / \mathrm{kg}$ for Ni, 0 to $19.2 \mathrm{mg} / \mathrm{kg}$ for $\mathrm{Pb}$, and 0 to $8.25 \mathrm{mg} / \mathrm{kg}$ for $\mathrm{Cr}$. Moreover, the concentrations of organochloride pesticides in samples were usually determined to be lower than their maximum residue level values given the pesticide residue limit regulation of Turkish Food Codex.
\end{abstract}

Keywords: Tilia tomentosa L.; Heavy metals; Organochloride pesticides; FAAS; GC-MS.

\section{Introduction}

Heavy metals and pesticides, found at different forms in ecological system, lead to serious destructive injuries on biological structures of living cells when they are taken at high concentrations ${ }^{[1]}$. In case of exposure for a long time to chloride pesticides and some heavy metals, such as $\mathrm{Cd}$, cancer cases can occur because of their endocrine disruptive effects, or it can result in death directly in case of exposure at high dosages for a short time ${ }^{[2-5]}$. Trace elements have significant roles in plant structures for life functions. Some elements are quite toxic to living beings and some are basic elements. However, basic elements can display toxic effects if they are taken at high dosages ${ }^{[6]}$.

It is known that metals, such as $\mathrm{Pb}, \mathrm{Ni}$, and $\mathrm{Cr}$ are toxic and carcinogenic, while metals, such as $\mathrm{Fe}, \mathrm{Zn}, \mathrm{Mn}$, and $\mathrm{Cu}$ are necessary for our biological systems ${ }^{[7]}$. For human beings, maximum metal concentrations that can be obtained from foods should be 10-18, 15, 2.5-5, 2-3 mg for $\mathrm{Fe}, \mathrm{Zn}, \mathrm{Mn}$, and $\mathrm{Cu}$, respectively ${ }^{[8]}$. World health organization has reported acceptable weekly intake as 0.007 and $0.025 \mathrm{mg} / \mathrm{kg}$ for $\mathrm{Pb}$ and $\mathrm{Cd}$ metals, respectively ${ }^{[9]}$. Acute $\mathrm{Cd}$ poisoning in humans is excessively damaging to tissues; such as high blood pressure, kidney damages, and destructions of testicular tissue and red blood cells ${ }^{[10-12]}$. Cd mostly accumulates in kidneys, and it can lead to kidney failure at high levels. Also, high level Cd intake can cause stomachache, vomiting, bone breakage, reproductive impairment, immune system impairment, DNA damage, and cancer ${ }^{[13]}$. Furthermore, there is sufficient evidence for a relation between lung cancer and nickel sulfate and nickel sulfurs ${ }^{[14]} . \mathrm{Pb}$ is a metal that has excessively poisoning properties. According to World Health Organization, acceptable weekly $\mathrm{Pb}$ intake is $25 \mu \mathrm{g} / \mathrm{kg}$ body weights because of its extremely toxic properties $^{[15,16]}$. Co is an essential element for B12 vitamin at living species, but it is very toxic at high level intakes ${ }^{[17]}$. Also, it was determined that high $\mathrm{Cu}$ levels higher than $2 \mathrm{mg} / \mathrm{kg}$ in drinking water caused vomiting, stomachache, and nausea ${ }^{[17,18]}$.

Organochloride pesticides are components that need to be tracked and inspected for pollution controls and health

Copyright (C) 2019 Osman Üner et al.

doi: $10.24294 /$ sf.v1i2.789

EnPress Publisher LLC.This work is licensed under the Creative Commons Attribution-NonCommercial 4.0 International License (CC BY-NC 4.0).

http://creativecommons.org/licenses/ by/4.0/ 
protections because organochloride pesticides stay active in environment for a long time, have biological accumulation properties and potential hazards to environment and living bodies. Organochloride pesticides can remain without degradation for a long time, dissolve in lipids, and their biological degradations and bio-transformations are too slow. Therefore, organochloride pesticides display unfavorable effects by causing various lives bio-magnifications, and also they were determined to be able to reach human beings via food chain ${ }^{[19]}$. Insecticides can move away from a region to another region by means of winds and insect movements and affect environment adversely. In the atmosphere, the most found organochlorine compounds among the insecticides are DDT, $\alpha-\mathrm{HCH}, \gamma-\mathrm{HCH}$ (lindan), heptachlor, dieldrin ${ }^{[20,21]}$. The plants take pesticides to their structures directly or indirectly from soil, water, and air, and then these pesticides join the food chain when used by living species ${ }^{[22-26]}$. Hence, pesticides and their amounts in nature continuously need to be tracked and determined to take their damages under control.

Turkey is the one of the developing countries in the world, but fast industrialization and unconscious activities have brought about environmental problems. The amounts of pollutions and heavy metals have increased in Turkey because of increasing traffic density, urbanization, and fast industrialization ${ }^{[27]}$. In this study, heavy metals $(\mathrm{Pb}$, $\mathrm{Ni}, \mathrm{Cu}, \mathrm{Mn}, \mathrm{Cd}, \mathrm{Cr}, \mathrm{Co}, \mathrm{Zn}, \mathrm{Mo}$, and $\mathrm{Fe}$ ) and organochloride pesticides ( $2 \mathrm{BHC}$ : $\alpha-\mathrm{BHC}, \beta-\mathrm{BHC}, \gamma-\mathrm{BHC}$, and $\delta$-BHC], ¿DDT: [4,4'-DDD, 4,4'-DDE, and 4,4'-DDT], $\alpha$-Endosulfan, $\beta$-Endosulfan, Endosulfan sulfate, Heptachlor, Heptachlor-endo-epoxide, Aldrin, Dieldrin, Endrin aldehyde, Endrin ketone, Endrin and Methoxychlor) were analyzed in the mixture of leaves and flowers from linden trees in Kırklareli, Turkey. For this aim, flame atomic absorption spectroscopy (FAAS) was used after the samples were dissolved with microwave method, and gas chromatography mass spectroscopy (GC-MS) was utilized after the samples were prepared for analyses by using QuEChERS method.

\section{Experimental}

\subsection{Study Area and Sample Collection}

As a bio monitor for the determination of heavy metals and pesticides, leaves and flowers from linden trees were collected in five different regions in Kırklareli, Turkey, seen in Figure 1. Kurklareli province borders the province of Istanbul to the southeast, the province of Tekirdag to the south, and the province Edirne to the west. Also, Kirklareli neighbours Bulgaria to the north, and its total population, including villages too, is 356,050 (year 2017). In Figure 1, traffic density relations of sample collection areas are $1<4<2<3<5$, and the coordinates of these sites are given in Table 1. Moreover, site 1 has been determined as control point because the population of site 1 is 250 , and agriculture and livestock breeding are significant in site 1 .

Linden trees (Tilia tomentosa L.) grow abundantly in Kırklareli. Linden is from the plant family of Tiliaceae, and a linden tree can reach a height of 20 to 30 meters. The leaves of linden trees grow to $5-10 \mathrm{~cm}$, and the leaves and flowers of linden trees are widely used to make tea in Turkey. Also, linden tea consumptions increase in cold months because of its curative effects. The samples collected in these five regions were washed with tap water and then with ultra-distilled water. After that, the samples were dried at $35^{\circ} \mathrm{C}$ and homogenized in an agate mortar for each sample separately.

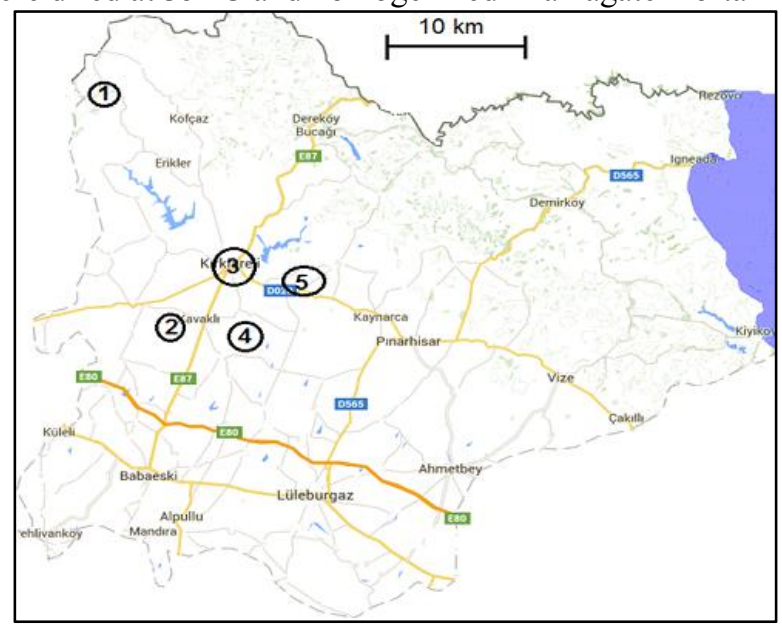

Figure 1; Collection areas of the leaves and flowers from linden trees in Kirklareli province. 


\begin{tabular}{|l|l|l|l|l|l|l|l|l|}
\hline & & \multicolumn{2}{|l|}{ Latitude N } & \multicolumn{3}{l|}{ Longitude E } \\
\hline Region & & $\circ$ &, & $\prime$ & & $\circ$ & $\prime$ & \\
\hline 1 & 41 & 58 & 49.138 & & 27 & 0 & 48.438 \\
\hline 2 & 41 & 38 & 37.086 & & 27 & 7 & 26.360 \\
\hline 3 & 41 & 43 & 47.143 & & 27 & 14 & 10.792 \\
\hline 4 & 41 & 37 & 37.693 & & 27 & 14 & 10.558 \\
\hline 5 & 41 & 41 & 49.373 & & 27 & 20 & 14.085 \\
\hline
\end{tabular}

Table 1. Coordinates of each sampling region in Kırklareli province

\subsection{Reagents}

All chemical reagents used are Merck and they have analytical grades. Metal standards (SRM; standard reference material) are NIST stock solutions with 1000 ppm. Dr. Ehrenstorfer organochlorine pesticide Mix 2 (HCH; hexachlorocyclohexane $(\alpha, \beta, \gamma, \delta)$, Heptachlor, Heptachlor-endo-epoxide, Aldrin; HHDN, $\alpha$-Endosulfan, 4,4'-DDE, 4,4'-DDD, 4,4'-DDT, Dieldrin, Endrin, $\beta$-Endosulfan, Endrin-aldheyde, Endosulfan-sulfate, Endrin-ketone, Methoxychlor) was used as organochloride pesticide standards for residue analysis. Structural formulas of organochlorine pesticides are given in Figure 2. In cleaning phases, all materials, such as Erlenmeyer flasks, beakers, plastics, etc., used in experiments were cleaned by washing with detergent water, and then rinsed with plenty of water. After that, these materials were soaked in $\mathrm{HNO}_{3}(10 \%, \mathrm{v} / \mathrm{v})$ before rinsing with distilled water and drying in an incubator.

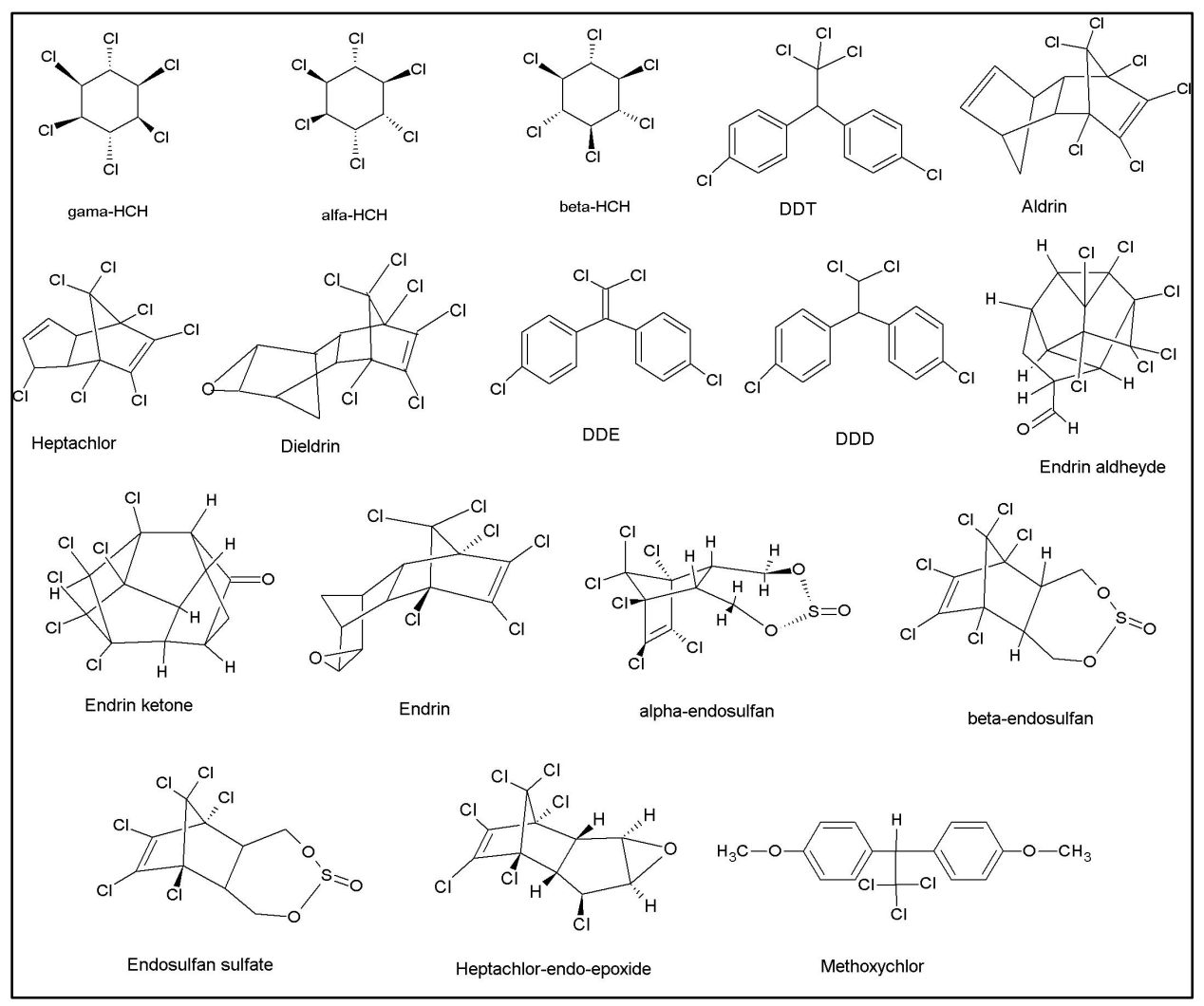

Figure 2; Structural formulas of organochlorine pesticides

\subsection{Preparation of Metal and Organochloride Standard Solutions}

From the stock solutions of $1000 \mathrm{ppm}$, the solutions with $50 \mathrm{ppm}$ were prepared by diluting with ultra-distilled water. Then, these standard solutions were adjusted to $0.01-1.0 \mathrm{mg} / \mathrm{L}$ for $\mathrm{Cd}, 0.1-2.0 \mathrm{mg} / \mathrm{L}$ for $\mathrm{Pb}, 0.5-10.0 \mathrm{mg} / \mathrm{L} \mathrm{for} \mathrm{Fe}$, 0.1-2.5 mg/L for Cr, 0.5-5.0 mg/L for Mo, 0.1-2.0 mg/L for Ni, 0.1-5.0 mg/L for Mn, 0.05-2.5 mg/L for Cu, 0.1-2 mg/L for $\mathrm{Zn}$ measurements. For organochlorine pesticide, $2000 \mathrm{ng} / \mu \mathrm{l}$ for $1 \mathrm{~mL}$ was prepared in the mixture of toluene/hexane 
(1/1). From the stock solution, standard solutions with 5, 10, 25, 50, 100, 500, and 1000 ppb were prepared by diluting in hexane. At the optimization studies, the organochloride pesticide standard with $100 \mathrm{ppb}$ was used.

\subsection{Methods}

Metal analyses were achieved by using FAAS (Agilent, 240 Duo), and the parameters related to measurements are presented in Table 2. Also, correlation coefficients (R2) of all metal standards were determined to be higher than 0.99 from their calibration curves.

\begin{tabular}{|c|c|c|c|c|c|c|c|}
\hline \multirow{2}{*}{ Element } & \multirow{2}{*}{ Wavelength (nm) } & \multirow{2}{*}{$\begin{array}{l}\text { Slit width } \\
\text { (nm) }\end{array}$} & \multirow{2}{*}{$\begin{array}{l}\text { Lamp } \\
(\mathrm{mA})\end{array}$} & \multirow[t]{2}{*}{ current } & \multicolumn{3}{|c|}{ Flow range of flame gases $(\mathrm{L} / \mathrm{min})$} \\
\hline & & & & & Air & Acetylene & $\mathrm{N}_{2} \mathrm{O}$ \\
\hline $\mathrm{Pb}$ & 217.0 & 0.7 & 4.0 & & 13.5 & 2.0 & - \\
\hline $\mathrm{Ni}$ & 352.5 & 0.2 & 4.0 & & 13.5 & 2.0 & - \\
\hline $\mathrm{Cd}$ & 228.8 & 0.5 & 4.0 & & 13.5 & 2.0 & - \\
\hline $\mathrm{Fe}$ & 248.3 & 0.2 & 5.0 & & 13.5 & 2.0 & - \\
\hline $\mathrm{Mn}$ & 279.5 & 0.2 & 5.0 & & 13.5 & 2.0 & - \\
\hline $\mathrm{Zn}$ & 213.9 & 1.0 & 5.0 & & 13.5 & 2.0 & - \\
\hline Mo & 313.3 & 0.5 & 7.0 & & - & 6.5 & 9.5 \\
\hline $\mathrm{Cu}$ & 324.8 & 0.5 & 10.0 & & 13.5 & 2.0 & - \\
\hline $\mathrm{Cr}$ & 357.9 & 0.2 & 7.0 & & - & 6.8 & 10.0 \\
\hline
\end{tabular}

Table 2. Parameters related to metal analysis measurements by using FAAS

Qualitative analyses of organochloride pesticides were carried out by GC-MS (Agilent) with HP-5 MS IU capillary column $(30 \mathrm{~m} \times 250 \mu \mathrm{m} \times 0.25 \mu \mathrm{m})$ and 5975C inert MSD mass detector. At these analyses, electron ionization system with ionization energy of $70 \mathrm{eV}$ was utilized, and He was used as carrier gas. Flow rate and injection volume were adjusted to $1 \mathrm{~mL} / \mathrm{min}$ and $1 \mu \mathrm{L}$, respectively. Column oven temperature was hold $110{ }^{\circ} \mathrm{C}$ for 5 min, and it was increased to $320{ }^{\circ} \mathrm{C}$ with the rate of $5{ }^{\circ} \mathrm{C} / \mathrm{min}$, finally hold at $320{ }^{\circ} \mathrm{C}$ for $8 \mathrm{~min}$. For the determination of volatile compounds, analysis time was adjusted to $22 \mathrm{~min}$. The characterizations of organochloride pesticides were achieved by utilizing NIST library. The mixture including 18 different organochloride pesticides was scanned at GC/MS, seen in Figure 3. Also, selected organochloride pesticides in SIM mode and retention times of organochloride pesticides at GC-MS were presented in Table 3. Moreover, correlation coefficients $\left(\mathrm{R}^{2}\right)$ of all organochloride pesticide standards were determined to be higher than 0.99 from their calibration curves.

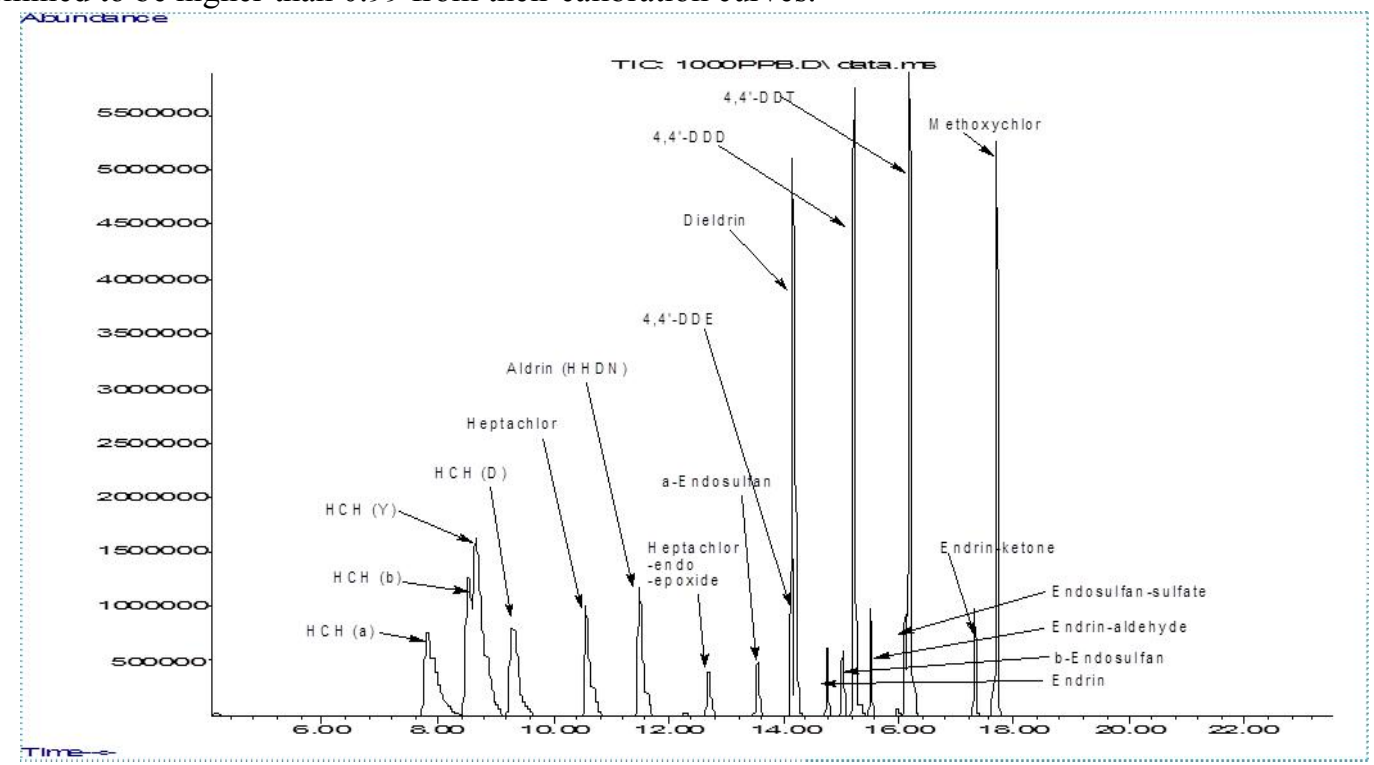

Figure 3; GC-MS chromatogram of organochlorine pesticides. 


\begin{tabular}{|l|l|l|l|l|}
\hline organochloride pesticides & $\begin{array}{l}\text { Retention time } \\
(\mathbf{m i n})\end{array}$ & Intense peak & $\begin{array}{l}\text { Selected ion } \\
\text { peak 1 }\end{array}$ & $\begin{array}{l}\text { Selected ion } \\
\text { peak 2 }\end{array}$ \\
\hline$\alpha$-HCH & 7.816 & 181 & 219 & 183 \\
\hline$\beta$-HCH & 8.501 & 219 & 181 & 183 \\
\hline$\gamma$-HCH & 8.666 & 181 & 183 & 219 \\
\hline$\delta$-HCH & 9.282 & 183 & 217 & 181 \\
\hline Heptachlor & 10.578 & 272 & 274 & 270 \\
\hline Aldrin (HHDN) & 12.674 & 263 & 265 & 261 \\
\hline Heptachlor-endo-epoxide & 11.501 & 217 & 185 & 253 \\
\hline Alpha-Endosulfan & 13.516 & 237 & 195 & 239 \\
\hline $4,4^{\prime}-\mathrm{DDE}$ & 14.146 & 246 & 318 & 316 \\
\hline Dieldrin & 14.198 & 263 & 277 & 279 \\
\hline Endrin & 14.765 & 263 & 265 & 261 \\
\hline beta-Endosulfan & 15.006 & 195 & 237 & 165 \\
\hline $4,4^{\prime}$-DDD & 15.231 & 235 & 237 & 165 \\
\hline Endrin-aldheyde & 15.502 & 345 & 67 & - \\
\hline Endosulfan-sulfate & 16.112 & 272 & 274 & 229 \\
\hline 4,4 '-DDT & 16.192 & 235 & 237 & 165 \\
\hline Endrin-ketone & 17.302 & 67 & 317 & - \\
\hline Methoxychlor & 17.666 & 227 & 228 & - \\
\hline
\end{tabular}

Table 3. Selected organochloride pesticides in SIM mode and retention times of organochloride pesticides at GC-MS.

\subsection{Solubilization of Linden Samples by Microwave for FAAS}

$0.5 \mathrm{~g}$ linden samples were solubilized in a microwave oven by using the mixture of nitric acid and hydrogen peroxide $(1: 2, \mathrm{v} / \mathrm{v})$. The analyses of $\mathrm{Mn}, \mathrm{Mo}, \mathrm{Cu}, \mathrm{Fe}, \mathrm{Zn}, \mathrm{Pb}, \mathrm{Ni}, \mathrm{Cd}$, and $\mathrm{Cr}$ in the linden samples made ready for analyses were achieved with six parallel samples at FAAS. The samples for $\mathrm{Fe}, \mathrm{Zn}$, and $\mathrm{Mn}$ were diluted ten times, and calculations were completed by taking into account dilutions.

\subsection{Extraction method for GC-MS}

Organochloride pesticides were analyzed by using QuEChERS method. After linden samples were homogenized, $10 \mathrm{~g}$ samples were taken into falcon centrifuge tubes with $50 \mathrm{~mL}$ volumes. Then, the samples were extracted by adding the mixtures of $5 \mathrm{~mL}$ ultra-distilled water and $40 \mathrm{~mL}$ hexane-dichloromethane $(1: 1, \mathrm{v} / \mathrm{v})$ in these falcon centrifuge tubes on Vortex mixer. After that, the samples were centrifuged at $7000 \mathrm{rpm}$ and $5{ }^{\circ} \mathrm{C}$ for $5 \mathrm{~min}$. After the separations of solid-liquid phase and organic phase, QuEChERS method was applied. First, organic phases were vortexed by adding AOAC 2007.01 Extraction kit (1.5 g sodium acetate and $6 \mathrm{~g} \mathrm{MgSO}_{4}$ in order to remove water from organic phase), and they were centrifuged at $7000 \mathrm{rpm}$ and $5{ }^{\circ} \mathrm{C}$ for $5 \mathrm{~min}$. Supernatants (QuEChERS dSPE) were passed through the cleaning column including $400 \mathrm{mg}$ PSA and $1200 \mathrm{mg} \mathrm{MgSO}$, and they were taken into centrifuge tubes by using vacuum manifold system. Subsequently, they were dried at the temperatures below $35^{\circ} \mathrm{C}$ under nitrogen atmosphere via evaporation system. Afterwards, dried samples were dissolved in $1 \mathrm{~mL}$ hexane, and they were taken into vials of $2 \mathrm{~mL}$ after passed from filters with $0.45 \mu \mathrm{l}$. Lastly, the prepared samples were analyzed with GC-MS, and their calculations were carried out by injecting into GC-MS five times for each sample.

\section{Results and Discussion}

\subsection{Metal analyses of SRMs and Linden Samples}

The solubilization method via microwave is the one of the widespread used methods for metal analyses in solid samples by atomic absorption spectroscopy. To test the accuracy of solubilization methods, various standards were used, 
and their analysis results are given in Table 4. By applying linden and spinach samples to SRM samples, optimized solubilization method was carried out with FAAS for the analyses of $\mathrm{Mn}, \mathrm{Cu}, \mathrm{Zn}, \mathrm{Fe}, \mathrm{Mo}, \mathrm{Cd}, \mathrm{Ni}, \mathrm{Pb}$, and $\mathrm{Cr}$. The metal contents in linden samples solubilized by microwave are presented in Table 5.

\begin{tabular}{|l|l|l|l|}
\hline Element & $\begin{array}{l}\text { Certificate value } \\
(\mathbf{m g} / \mathbf{k g})\end{array}$ & $\begin{array}{l}\text { Measured value } \\
(\mathbf{m g} / \mathbf{k g})\end{array}$ & $\begin{array}{l}\text { Recovey percentage } \\
(\%)\end{array}$ \\
\hline $\mathrm{Mn}$ & 76.00 & $72.5 \pm 1.0$ & 96 \\
\hline $\mathrm{Cu}$ & 12.20 & $11.9 \pm 0.2$ & 98 \\
\hline $\mathrm{Zn}$ & 82.30 & $77.4 \pm 2.1$ & 94 \\
\hline $\mathrm{Cd}$ & 2.88 & $2.84 \pm 0.09$ & 99 \\
\hline $\mathrm{Ni}$ & 2.14 & $2.11 \pm 0.07$ & 99 \\
\hline $\mathrm{Pb}$ & 0.20 & $0.21 \pm 0.01$ & 105 \\
\hline
\end{tabular}

Table 4. The certificate values, measured values, and recovery percentages of various metals in spinach standard (NIST-SRM 1570a, Spinach $)(n=6)$

As seen in Table 5, heavy metals $(\mathrm{Ni}, \mathrm{Pb}$, and $\mathrm{Cr}$ ) were not determined in linden samples collected from the regions with low traffic density (traffic densities: $1<4<2<3<5$ ), but the metal concentration values of linden samples collected from the regions near highways and industrial factories exceed the daily uptake limit of a person (especially for 3 and 5 regions). Furthermore, the concentrations of $\mathrm{Zn}, \mathrm{Fe}, \mathrm{Mo}$, and $\mathrm{Cd}$ in samples collected from 3 and 5 regions were determined to be higher compared to the other regions. The lowest metal concentrations in linden samples were found to be in region 1, except for Fe metal, and the high Fe concentration can be related to the soil structure in region 1. The lowest Fe concentration was measured to be $128 \pm 8 \mathrm{mg} / \mathrm{kg}$ (dry weight), while the highest Fe concentration was found to be $1310 \pm 120 \mathrm{mg} / \mathrm{kg}$ (dry weight). Thus, the leaves and flowers of linden trees can be a bio monitor for Fe metal.

\begin{tabular}{|c|c|c|c|c|c|}
\hline \multirow{2}{*}{ Element } & \multicolumn{5}{|l|}{ Regions } \\
\hline & 1 & 2 & 3 & 4 & 5 \\
\hline $\mathrm{Mn}$ & $45.3 \pm 1.4$ & $48.5 \pm 1.2$ & $91.3 \pm 5.8$ & $249 \pm 9$ & $268 \pm 7$ \\
\hline $\mathrm{Cu}$ & $0.25 \pm 0.01$ & $7.45 \pm 0.37$ & $3.99 \pm 0.02$ & $5.98 \pm 0.12$ & $18.8 \pm 0.2$ \\
\hline $\mathrm{Zn}$ & $11.5 \pm 0.6$ & $12.7 \pm 0.6$ & $30.5 \pm 1.1$ & $13.5 \pm 0.8$ & $46.1 \pm 1.6$ \\
\hline $\mathrm{Fe}$ & $321 \pm 23$ & $128 \pm 8$ & $1047 \pm 80$ & $159 \pm 11$ & $1310 \pm 120$ \\
\hline Mo & $10.4 \pm 0.4$ & $18.2 \pm 0.7$ & $30.7 \pm 1.7$ & $23.9 \pm 1.5$ & $38.6 \pm 1.8$ \\
\hline $\mathrm{Cd}$ & $0.82 \pm 0.05$ & $0.87 \pm 0.06$ & $1.11 \pm 0.07$ & $0.94 \pm 0.08$ & $1.34 \pm 0.12$ \\
\hline $\mathrm{Ni}$ & ND & $1.07 \pm 0.11$ & $1.44 \pm 0.13$ & $1,13 \pm 0.11$ & $6.45 \pm 0.32$ \\
\hline $\mathrm{Pb}$ & ND & ND & $12.0 \pm 0.5$ & ND & $19.2 \pm 0.1$ \\
\hline $\mathrm{Cr}$ & ND & ND & $3.71 \pm 0.35$ & ND & $8.25 \pm 0.78$ \\
\hline
\end{tabular}

*ND: Not detected.

Table 5. Metal concentrations in leaves and flowers from linden trees $(\mathrm{mg} / \mathrm{kg}$, dry weight $)(\mathrm{n}=6)$

\subsection{Organochloride Pesticide Analyses of Linden Samples}

According to the pesticide residue limit regulation of Turkish Food Codex ${ }^{[28]}$, MRL (maximum residue level) values for linden samples are given in Table 6. To test the accuracy of analysis method, recovery experiments were carried out by using standard addition method, and it was determined that the sensitivity of the analysis method done for each organochloride pesticide was good. At standard addition step, each sample was separated into four parts, and first part was completed $1 \mathrm{~mL}$ with hexane. By using $1000 \mathrm{ppb}$ standard solution, second, third and fourth parts were adjusted to 10,25 , and $50 \mathrm{ppb}$, respectively, and then the last volumes were completed $1 \mathrm{~mL}$. All solutions were measured at GC-MS, and correlation coefficients $\left(\mathrm{R}^{2}\right)$ were determined to be higher than 0.99 from their calibration curves. By calculating real concentration values for linden samples, organochloride pesticide concentrations are presented in Table 6 . 
The concentrations of $\sum$ DDT, Heptachlor, Heptachlor-endo-epoxide, $\alpha$-Endosulfan, $\beta$-Endosulfan, Endosulfan-sulfate, Endrin-ketone, and Methoxychlor in samples were determined to be lower than their maximum residue level values (MRLs). On the other hand, the concentrations of $\sum \mathrm{HCH}$, Aldrin, and Dieldrin are close to their MRL values. Also, the values of Endrin and Endrin-aldheyde in the samples collected from region 5 were detected to be 1.5-2 times higher than their MRLs. Moreover, Endrin concentrations in the samples have the highest values compared to the other organochloride pesticides in samples collected from all regions, except for Endrin-aldheyde in the sample collected from region 5. Pesticides can reach the leaves and flowers of linden trees not only from soil but also air by winds; therefore, pesticides fallen to the leaves and flowers of linden trees may penetrate in the leaves and flowers, or they may be adsorbed on the surfaces. These high Endrin concentrations can be caused by intensive agricultural activities at regions or their neighbor regions.

\begin{tabular}{|c|c|c|c|c|c|c|}
\hline \multirow{2}{*}{ Pesticides } & \multirow{2}{*}{ MRL } & \multicolumn{5}{|l|}{ Regions } \\
\hline & & 1 & 2 & 3 & 4 & 5 \\
\hline$\alpha-\mathrm{HCH}$ & 0.02 & $25.6 \pm 0.7$ & $25.7 \pm 0.7$ & $26.2 \pm 0.6$ & $25.9 \pm 0.6$ & $27.0 \pm 0.6$ \\
\hline$\beta-\mathrm{HCH}$ & 0.02 & $30.5 \pm 0.5$ & $30.8 \pm 0.6$ & $31.5 \pm 0.5$ & $31.2 \pm 0.6$ & $31.6 \pm 0.5$ \\
\hline$\gamma-\mathrm{HCH}$ & 0.02 & ND & $26.0 \pm 2.3$ & $25.9 \pm 2.4$ & $27.7 \pm 2.6$ & $30.7 \pm 2.9$ \\
\hline$\delta-\mathrm{HCH}$ & 0.02 & $26.7 \pm 0.1$ & $26.8 \pm 0.1$ & $26.8 \pm 0.1$ & $26.8 \pm 0.1$ & $26.8 \pm 0.1$ \\
\hline Heptachlor & 0.1 & $36.4 \pm 0.6$ & $37.3 \pm 0.7$ & $41.2 \pm 0.8$ & $36.6 \pm 0.9$ & $50.0 \pm 0.9$ \\
\hline Aldrin & 0.02 & $22.6 \pm 0.4$ & $22.8 \pm 0.3$ & $23.2 \pm 0.4$ & $23.5 \pm 0.4$ & $23.5 \pm 0.3$ \\
\hline Heptachlor-endo-epoxide & 0.1 & $29.2 \pm 2.8$ & $33.8 \pm 3.3$ & $35.9 \pm 3.5$ & $34.2 \pm 3.3$ & $38.3 \pm 3.7$ \\
\hline$\alpha$-Endosulfan & 0.1 & ND & ND & ND & ND & ND \\
\hline 4,4'-DDE & 0.5 & $24.8 \pm 0.2$ & $24.2 \pm 0.1$ & $24.4 \pm 0.2$ & $24.4 \pm 0.2$ & $24.5 \pm 0.2$ \\
\hline Dieldrin & 0.02 & $33.2 \pm 2.0$ & $33.8 \pm 1.9$ & $35.2 \pm 1.9$ & $36.4 \pm 1.8$ & $37.2 \pm 1.9$ \\
\hline Endrin & 0.1 & $134 \pm 13$ & $66.3 \pm 6.5$ & $105 \pm 11$ & $92.4 \pm 9.3$ & $144 \pm 14$ \\
\hline$\beta$-Endosulfan & 0.1 & $25.7 \pm 0.5$ & $26.8 \pm 0.5$ & $26.4 \pm 0.7$ & $26.9 \pm 0.6$ & $26.8 \pm 0.6$ \\
\hline 4,4'-DDD & 0.5 & $30.0 \pm 0.1$ & $29.8 \pm 0.1$ & $29.8 \pm 0.1$ & $29.8 \pm 0.1$ & $29.8 \pm 0.2$ \\
\hline Endrin-aldheyde & 0.1 & ND & $145 \pm 13$ & ND & $28.8 \pm 2.6$ & $220 \pm 21$ \\
\hline Endosulfan-sulfate & 0.1 & $32.8 \pm 0.1$ & $32.9 \pm 0.1$ & $32.9 \pm 0.1$ & $32.8 \pm 0.1$ & $32.9 \pm 0.1$ \\
\hline 4,4'-DDT & 0.5 & $36.8 \pm 0.7$ & $35.6 \pm 0.5$ & $35.6 \pm 0.2$ & $35.6 \pm 0.4$ & $35.6 \pm 0.8$ \\
\hline Endrin-ketone & 0.1 & $33.1 \pm 2.5$ & $28.8 \pm 2.4$ & $28.9 \pm 2.2$ & $30.1 \pm 2.1$ & $29.7 \pm 2.2$ \\
\hline Methoxychlor & 0.1 & $39.8 \pm 0.1$ & $39.5 \pm 0.2$ & $39.5 \pm 0.2$ & $39.7 \pm 0.1$ & $39.5 \pm 0.1$ \\
\hline
\end{tabular}

Table 6. Organochlorine pesticide concentrations ( $\mu \mathrm{g} / \mathrm{kg}$, dry weight) in the leaves and flowers from linden trees and their MRL values $(\mathrm{mg} / \mathrm{kg})$

\section{Conclusions}

This work was achieved to obtain information about metal and organochloride pesticide concentrations in the leaves and flowers of linden trees in Kirklareli province. Flame atomic absorption spectroscopy was used after the samples were dissolved with microwave method, and gas chromatography mass spectroscopy was utilized after the samples were prepared for analyses by using QuEChERS method. Heavy metal concentrations in the linden samples collected from urban settlements with high traffic densities were usually determined to be higher than those in the linden samples collected from rural areas. Also, the concentrations of organochloride pesticides in samples were usually determined to be lower than their maximum residue level values, but Endrin and Endrin-aldheyde concentrations in the samples collected from region 5 were detected to be 1.5-2 times higher than their MRLs. 


\section{Acknowledgements}

We appreciate Kurklareli University because of its support and permission us to use devices, such as FAAS, GC-MS, microwave oven, etc. in the central laboratory, and we thank to Kırklareli University Research Fund for its financial supports under the project number of KLÜBAP/092.

\section{References}

1. M Okcu, E Tozlu, AM Kumlay,et al. Alınteri 17 (2009) 14-26.

2. A Alvarez, JM Saez, JS Davila Costa, et al. Chemosphere 166 (2017) 41-62.

3. LS Kjeldsen, M Ghisari, EC Bonefeld-Jorgesen, et al.. Appl. Pharma. 272 (2013) 453-464.

4. $\quad$ S Ozcan, ME Aydin, Atmospher. Resear. 93 (2009) 715-722.

5. N Abdelouahab, D Mergler, L Takser, et al. Environ. Res. 107 (2008) 380-392.

6. H Avci, M Yaman, Water air soil pollut. 225 (2014) 1926.

7. W Mertz, Trace Elements in Human and Animal Nutrition, 5th ed., Academic Press, Newyork, 2012.

8. G Thorvaldsson, Essential Trace Elements for Plants, Animals and Humans, ISSN 1670-5785, Agricultural University of Iceland, 2005.

9. WHO (World Health Organization), Fifty-Third report of the Joint FAO/WHO Expert Committee on Food Additives, WHO Technical Report Series 896, Geneva, Switzerland, 2000.

10. B Eugenio Figueroa, Sci. Total Environ. 389 (2008) 1-9.

11. M Andac, R Say, A Denizli, et al. 811 (2004) 119-126.

12. Stanley E Manahan, Environmental Science, Technology, and Chemistry, Environmental Chemistry, Boca Raton: CRC Press LLC, 2000.

13. MP Waalkes, Mutat. Resear. 533 (2003) 107-120.

14. IARC, Chromium, nickel and welding, IARC Monographs on the Evaluation of Carcinogenic Risks to Humans, vol. 49, Lyon, France, 1990.

15. WHO (World Health Organization), Sixty-Third Report Of The Joint Fao/Who Expert Committee On Food Additives, WHO Technical Report Series 928, Geneva, Switzerland, 2005.

16. WHO (World Health Organization), Trace Elements in Human Nutrition and Health, WHO Library Cataloguing in Publication Data, Geneva, 1996.

17. L Patrick, Alternat. Med. Rev. 11 (2006) 114-127.

18. I Narin, M Soylak, Analyt. Chimica Acta 493 (2003) 205-212.

19. N Vural, Ankara Üniversitesi Eczacılık Fakültesi Yayınları 73 (2005) 342 -363.

20. O Erkmen, Çocuk Sağlı̆̆ı ve Hastalıkları Dergisi 53 (2010) 220-235.

21. LM Nollet, Organochlorine pesticides: Hand Book of Water Analysis CRC Press, 2000, p. 520-522.

22. WHO, Environmental Health Criteria 240, Principles and methods for the risk assessment of chemicals in food, ISBN 978924157240 8, Germany, 2009.

23. WHO, Guidelines for assessing quality of herbal medicines with reference to contaminants and residues, ISBN 978924159444 8, Switzerland, 2007.

24. WHO, Guidelines for Predicting Dietary Intake of Pesticide Residues (revised), WHO/FSF/FOS/97.7, Geneva, Switzerland, 1997.

25. WHO, Application of Risk Analysis to Food Standards Issues, Report of the Joint FAO/WHO Expert Consultation, WHO/FNU/FOS/95.3, Geneva, Switzerland, 1995.

26. J Jurewicz, W Hanke, Internat J. Occup. Neurobeh. Develop. 21 (2008) 121-132.

27. O Munzuroglu, N Gur, Turk J Biol. 24 (2000) 677-684.

28. Turkish Food Codex, Türk gıda kodeksi pestisitlerin maksimum kalıntı limitleri yönetmeliği, 2016, T.C. Resmi Gazete, 29899, 25.11.2016. 